\title{
Parametric Seismic Study of Steel-Concrete Composite Frames
}

\author{
Syed Kaleem Afrough Zaidi ${ }^{1}$ | Shobharam ${ }^{2}$ | Imran $^{2}$
}

${ }^{1}$ Associate Professor, Civil Engineering Section AMU Aligarh, India

${ }^{2}$ Assistant Professor, School of Engineering G. B. University, Greater Noida, India

${ }^{2}$ PG Scholar, School of Engineering, G. B. University, Greater Noida, India.

\section{To Cite this Article}

Syed Kaleem Afrough Zaidi, Shobharam and Imran, "Parametric Seismic Study of Steel-Concrete Composite Frames", International Journal for Modern Trends in Science and Technology, 6(9): 24-30, 2020.

Article Info

Received on 06-August-2020, Revised on 20-August-2020, Accepted on 25-August-2020, Published on 29-August-2020.

\section{ABSTRACT}

In India mostly multi story buildings are constructed with reinforced concrete,steel and recently the trend of construction is going toward composite structure which has beenstarted is in growing stage.Therefore the main aim of this research is to the parametric study on reinforced concrete, steel and steel- concrete composite frames. A $3 D(G+9)$ stories building is situated in seismic zone IV and designed for same gravity loads. The reinforced beam and column were design according to the IS: 456-2000 and the composite fill sections were design according American standard AISC: 360-10.Further the beam and column sections were made by reinforced concrete, steel and steel-concrete composite. The reinforced concrete slab of uniform thickness was considering for all type of frames. Load combination is assigned according to IS: 1893-2002. The entire frame were modeled and analyzed by response spectrum method using E-tabs software 2015. Finally the results were obtained and compared in a parametric study. This study concludes that composite frame show better performance compared to reinforced concrete and steel frames.

Key words:Steel-concrete composite, Seismic behavior, ETABS Software, Storey drift, Overturning moment etc.

\section{INTRODUCTION}

The most significant and most unusually experienced bring together of enlargement materials is the steel and concrete. Reinforced concrete has been the most popular construction material worldwide due to its extremely good properties. However the seismic performance of reinforced concrete systems during past earthquakes,forced the researchers to find an alternative materials of construction. The steel is being a ductile material, enough strength and warning earlier than failure through way of immoderate deformations. These properties of steel are of very plenty important in case of the seismic resistant design. Thus, a comparative have a look at is essential to be done from the factor of view of seismic performance.Composite steel concrete structures are used widely in modern bridge and building construction and this system of construction is gaining popularity as multifaceted design and construction technique. Therefore in multistory structure, structural steelwork is regularly utilized together with concrete; for instance, steel beams with concrete floor slabs. Further concrete filled tube sections are one of the 
best composite sections that have many benefits over conventional steel and reinforced concrete sections. These sections are formed by filling concrete into a hollow steel tube section and offers resistance to carry out load through the composite action of steel and concrete. Concrete filled tube section possesses high ductility, energy, and strength absorption potential that are very vital for a shape placed in earthquake susceptible areas. In composite column construction steel and concrete are united in such a manner that the advantages of the materials are employed in a efficient manner and Concrete filled tube column is most popular in the steel-concrete composite frame. Based at the form of cross-phase, Concrete filled tube sections are labeled into numerous sorts' namely ordinary concrete filled tube section, concrete filled tube phase with reinforcement, concrete filled double pores and skin tubes, and concrete encased concrete filled tube section. inthis study, focus on the performance of the reinforced concrete, steel and steel-concrete composite and the concrete filled tube frame structure during earth quake which is building is situated in seismic zone $\mathrm{v}$ and also compares the seismic parameters results and analysis was done using E-tabs software 2015. An overview of previous research on reinforced concrete structure, steel structure and steel-concrete composite structure and their seismic parameters such as story drift, base shear, story stiffness, overturning moment, story displacement etc. D. R. Panchal , P. M. Marathe (2011) explained the comparative study of reinforced cement concrete, steel and composite building. They analyzed the $(\mathrm{G}+30)$ storey commercial building which is situated in earthquake zone IV and building plan is selected with area covering $24 \mathrm{~m} \times 42 \mathrm{~m}$. For modeling of composite, steel and reinforced cement concrete structure, use the ETABS software and found that composite structure was to beeconomical. A N. Shah, P.S. Pajgade (2013) explain the comparison of R.C.C and composite multi-storied buildings. $\mathrm{G}+15$ storied building located in seismic zone IV and wind velocity $39 \mathrm{~m} / \mathrm{s}$. The plan dimension of the building is $25.61 \mathrm{mx} 15.92 \mathrm{~m}$ and height of each storey is kept same as $3.35 \mathrm{~m}$ and the total height of the building is $56.5 \mathrm{~m}$. Equivalent Static Method of Analysis is used. For modeling of composite \& R.C.C. structures, STAAD-pro software is used. The comparison of results of composite column building and R.C.C. column building shows that the deflection and storey drift in composite structure is nearly double than that of R.C.C. structures but the deflection is within the permissible limit. Composite structure is more economical than R.C.C. structure. S. A.Wagh, U.P Waghe(2014), present the comparative study of R.C.C. with steel, concrete composite were considered for the different $(\mathrm{G}+12, \mathrm{G}+16, \mathrm{G}+20$, $\mathrm{G}+24)$ stories buildings situated in Nagpur earthquake zone II and wind speed $44 \mathrm{~m} / \mathrm{s}$ was analyzed by using the STAAD-Pro software. Compare the cost analysis between the R.C.C and steel structure for four commercial building. It is found that composite structure is more economical than R.C.C structure and gives the speed in construction.Z. Mujawar, P.Sangave (2015) explained comparative evaluation of reinforced concrete, steel and composite structures under the effect of static and dynamic loads. In this paper, the behavior of reinforced concrete, steel and composite structures under the effect of seismic loading. The result parameters are base shear, displacement and inter-storey drift. After the result they see that base shear for composite structure has reduced by $31 \%$ and for steel structure $29 \%$ compared to that of reinforced concrete structure. Displacement for composite structure has increased by $48 \%$ and for steel structure by $49 \%$ comparedto that of R.C.C structure. Storey drift was also more compared to R.C.C and steel structure. Time required for composite structure was less than the other structuresH. Nausheen, H.Eramma(2015)An extensive study has been carried out on the behavior of composite column and conventional column and keeping all other structural members same for both the structures. The composite column design were carried out according to Euro code 4 and conventional column design by IS 456-2000. The Modeling of buildings was considered in III seismic zoneand analysis has been carried in ETABS software. Results were obtained of various parameters in terms of base shear, storey overturning, storey drift and concluded that low rise conventional building is more suitable than low rise composite building. $N$ .V. Ganwani, S. S. Jamkar(2016) in this paper acomparative study of seismic performance of a 3D $(\mathrm{G}+8)$ storey $\mathrm{RCC}$ and steel concrete composite building frame situated in earthquake zone IV considering the equivalent static method and response spectrum method were used for seismic analysis. ETAB 2015 software was used and results were compared and conclude that the composite construction is more economical than 
the conventional RCC construction.A.S. Boke, K. R. Suryawanshi(2017)the behavior of reinforced concrete, steel and composite structures under the effect of seismic loading and a comparative study of RCC and steel-concrete composite $(\mathrm{G}+10)$ residential building were studied.Response spectrum method was used for comparison of three structures with the help of ETABS software. The parameters were studied as base shear, displacement and inter-storey drift. Itisfoundthecompositestructuregivebetterresulttha n R.C.C structures. P. S. Sanjay, S. R. Parekar(2019) , Present the compare study on seismic performance of a $3 \mathrm{D}(\mathrm{G}+8)$ storey $\mathrm{RCC}$, Steel and Composite building frame situated in earthquake zone V. All frames are designed for same gravity loadings. The RCC slab is used in all three cases. Beam and column sections are made of RCC, Steel or Steel-concrete composite sections. Equivalent static method and response spectrum method are used for seismic analysis. ETABS 2015 software was used for analysis and results were reported based on fundamental time period, displacements, base shear and storey drift. Comparative study concludes that, RCC construction is best suited for low rise buildings among all the three types of constructions.T.G.N.C.Vamsi Krishna, S.V.Surendhar, M.S.R. Krishna.(2019) In this study a geometrically irregular residential building $(\mathrm{G}+18$ storey) was designed and analyzed for both cases of RCC and composite structures (considering earthquake zone III) using ETABS software. The structure wasanalyzed using linear static, linear and non-linear dynamic methods, such as equivalent static method, response spectrum method and time history method. From the observed results, it may be clearly inferred that a steel composite, performs well in-terms of structural integrity when compared with an RCC structure. M. AkifUddin, M. A. Azeem(2020)Discus the composite structure with concrete filled steel tubular columns, a composite structure with concrete encased I section columns and a RCC structure. All the models considered are G+15 storey and are irregular in plan and the irregularity condition as per IS 1893-2002 is satisfied resulting in T shape and Plus Shape models. It was observed after performing response spectrum analysis on the models that the stiffness is less in composite structures when compared to RCC structures. The displacements and drifts are less in RCC structures owing to larger value of stiffness but are within the permissible limits. The base shear and base moments are found to be less in composite structures due to the fact that the dead weight of composite structures is less compared to RCC structures. There is no significant difference in the response parameters of the two composite structures.

Modeling: Modeling of reinforced concrete, steel and steel-concrete composite structure are referring here to the design of slab, beam, column, material properties and loading conditions as taken in this study. Modeling and analysis of the structure is done using E-tabs software 2015 and analyzed by using response spectrummethod. In the study, six different type of building frame models having different materials properties were considered. The plan dimension of the building is $18 \times 27 \mathrm{~m}$ and the height of each storey for RC; steel and steel-concrete composite frame is $3 \mathrm{~m}$. The building having 3D $(G+9)$ storied located in seismic zone IV and for earthquake loading, the provisions of the Indian standard IS: 1893(Part1) 2002, the provisions of the IS: 456- 2000, provisions of the IS: 800-2007, and guide lines according to American standard AISC: $360-10$ were considered for the analysis respectively. The floor plans were divided into four by six bays in such a way that centre to centre distance between two grids is 4.5 meters by 4.5 meters respectively. This study is modeled to compared the seismic behavior of eight types of framed structure consisting of (i) Reinforced concrete slab, beam and column(ii) steel beam, steel column andreinforced concrete slab(iii) Steel column, reinforced concrete slab and beam(iv) steel beam, reinforced concrete slab and column(v) Concrete filled tube (CFT)rectangular beam and column and reinforced concrete slab(iv) (CFT)rectangular beam with I section encased both in beam and column and reinforced concrete slab(vii) (CFT) circular beam and column, reinforced concrete slab(viii) (CFT) circular beam with I section encased both in beam and column and reinforced concrete slab. The plan and 3D view of building is shown in figure 1 . Different sections and types of frames are listed in table 1 , and material propertiesand seismic data is given in table 2 . 


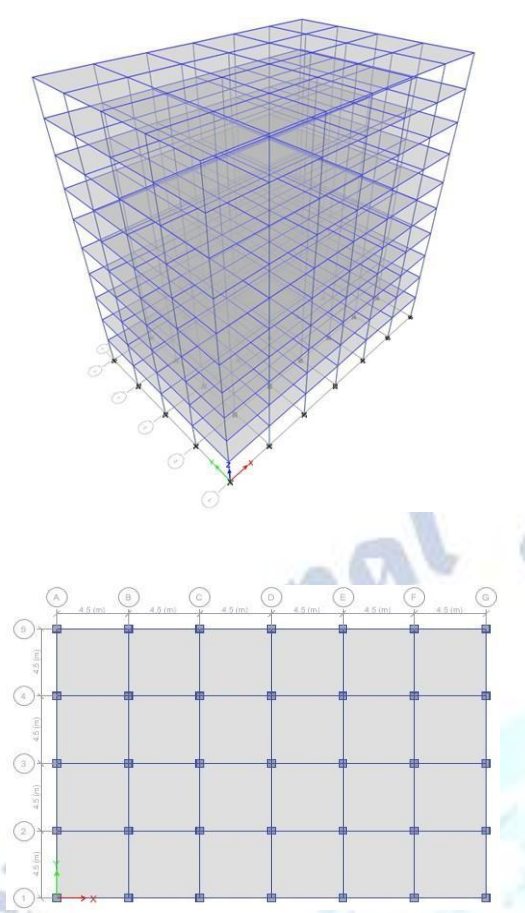

Figure 1.Plan and 3D view of the building

Table 1.Section used in the design of frames

\begin{tabular}{|c|c|c|c|}
\hline Types of frame & $\begin{array}{l}\text { Beam } \\
\text { dimension }\end{array}$ & $\begin{array}{l}\text { Column } \\
\text { dimension }\end{array}$ & Slab \\
\hline RC Frame & $250 \times 400 \mathrm{~mm}$ & $500 \times 500 \mathrm{~mm}$ & \\
\hline & Cross section & Cross section & $\begin{array}{l}120 \mathrm{~mm} \\
\text { thick RC } \\
\text { slab }\end{array}$ \\
\hline Steel Frame & ISMB 200 & $\begin{array}{l}\text { ISHB } 450-2 \\
\text { with } \\
40 \mathrm{~mm} \text { cover } \\
\text { plate }\end{array}$ & $\begin{array}{l}120 \mathrm{~mm} \\
\text { thick RC } \\
\text { slab }\end{array}$ \\
\hline $\begin{array}{l}\text { Composite } 1 \\
\text { frame }\end{array}$ & ISMB 250 & $\begin{array}{l}500 \text { X } 500 \mathrm{~mm} \\
\text { Cross section }\end{array}$ & $\begin{array}{l}120 \mathrm{~mm} \\
\text { thick RC } \\
\text { slab }\end{array}$ \\
\hline $\begin{array}{l}\text { Composite } 2 \\
\text { frame }\end{array}$ & $\begin{array}{l}250 \text { X } 400 \mathrm{~mm} \\
\text { Cross section }\end{array}$ & $\begin{array}{l}\text { ISMB } 500 \text { with } \\
40 \\
\text { mm cover plate }\end{array}$ & $\begin{array}{l}120 \mathrm{~mm} \\
\text { thick RC } \\
\text { slab }\end{array}$ \\
\hline CFT 1 frame & $\begin{array}{l}250 \times 400 \mathrm{~mm} \\
\text { CFT } \\
\text { With } 12 \mathrm{~mm} \\
\text { thick }\end{array}$ & $\begin{array}{l}500 \text { X } 500 \mathrm{~mm} \\
\text { CFT } \\
\text { With } 12 \mathrm{~mm} \\
\text { thick }\end{array}$ & $\begin{array}{l}120 \mathrm{~mm} \\
\text { thick RC } \\
\text { slab }\end{array}$ \\
\hline CFT 2 frame & $\begin{array}{l}250 \quad \mathrm{X} \quad 400 \\
\mathrm{~mm} \\
\text { CFT With } \\
\text { ISMB } \\
150 \text { steel } \\
\text { section }\end{array}$ & 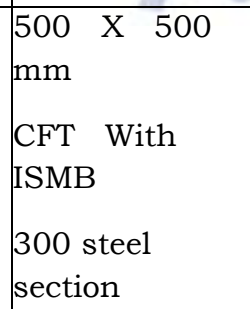 & $\begin{array}{l}120 \mathrm{~mm} \\
\text { thick RC } \\
\text { slab }\end{array}$ \\
\hline CFT 3 frame & $\begin{array}{l}250 \times 400 \mathrm{~mm} \\
\text { CFT With } 12\end{array}$ & $\begin{array}{l}500 \mathrm{~mm} \\
\text { diameter CFT }\end{array}$ & $\begin{array}{l}120 \mathrm{~mm} \\
\text { thick RC }\end{array}$ \\
\hline
\end{tabular}

\begin{tabular}{|c|c|c|c|}
\hline & \begin{tabular}{|l|}
$\mathrm{mm}$ \\
Thick
\end{tabular} & $\begin{array}{l}\text { column with } \\
12 \mathrm{~mm} \text { thick }\end{array}$ & slab \\
\hline CFT 4 frame & 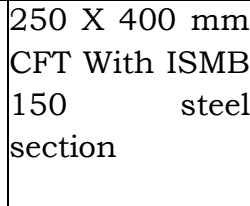 & $\begin{array}{lr}500 & \mathrm{~mm} \\
\text { diameter } & \text { CFT } \\
\text { column } & \text { with } \\
\text { ISMB 300 } & \text { steel } \\
\text { section } & \end{array}$ & $\begin{array}{l}120 \mathrm{~mm} \\
\text { thick RC } \\
\text { slab }\end{array}$ \\
\hline
\end{tabular}

Table 2 :Material propertiesand seismic data

\begin{tabular}{|c|c|c|c|}
\hline $\begin{array}{c}\text { Unit weight of } \\
\text { concrete }\end{array}$ & $\begin{array}{c}25 \\
\mathrm{kN} / \mathrm{m}^{3}\end{array}$ & Seismic zone & IV \\
\hline $\begin{array}{c}\text { Unit weight of } \\
\text { steel }\end{array}$ & $\begin{array}{c}78 \\
\mathrm{kN} / \mathrm{m}^{3}\end{array}$ & $\begin{array}{c}\text { Importance } \\
\text { factor (I) }\end{array}$ & 1 \\
\hline $\begin{array}{c}\text { Grade of concrete } \\
\mathrm{M} 30\end{array}$ & $\begin{array}{c}\text { Response } \\
\text { reduction } \\
\text { factor (R) }\end{array}$ & 5 (SMRF) \\
\hline $\begin{array}{c}\text { Grade of steel } \\
\text { sections }\end{array}$ & $\mathrm{Fe} 250$ & Soil type & Medium \\
\hline $\begin{array}{c}\text { Grade of } \\
\text { reinforcing } \\
\text { steel }\end{array}$ & $\mathrm{Fe} 415$ & $\begin{array}{l}\text { Response } \\
\text { spectrum } \\
\text { function }\end{array}$ & $\begin{array}{l}\text { IS } \\
1893: 2002 \\
\text { Spectrum }\end{array}$ \\
\hline $\begin{array}{c}\text { Modulus of } \\
\text { elasticity } \\
\text { for concrete }\end{array}$ & $\begin{array}{c}25 \\
\mathrm{kN} / \mathrm{m}^{2}\end{array}$ & $\begin{array}{c}\text { Function } \\
\text { damping }\end{array}$ & $5 \%$ \\
\hline $\begin{array}{c}\text { Modulus of } \\
\text { elasticity } \\
\text { for steel }\end{array}$ & $\begin{array}{c}210 \\
\mathrm{kN} / \mathrm{m}^{2}\end{array}$ & Zone factor (Z) & 0.24 \\
\hline
\end{tabular}

Results and discussion: In the present study,Response spectrum analysishas been performed using E-tabs software 2015and results of eight different types of models has been studied and compared with their parameters such as story drift, base shear, overturning moment, story stiffness, shear force etc. The objective of this study is to see the variation in the parameters value for different types of framesstructure.

Storydrift:The figure2 shows the storey drift valuesobtained in $\mathrm{X}$ and $\mathrm{Y}$ directions. It is observed that story drift in both the direction found more in steel frame as compared to other frame in this study. It is also seen the storey drift was more in $\mathrm{Y}$ direction compared to $\mathrm{X}$ direction. This may be due to the ductile behavior of steel and steel frame has low stiffness value. Further the lowest values are observed in CFT2 model compared to other frames. However all the values are within the permissible limit and satisfying the IS: 1893-2002. 


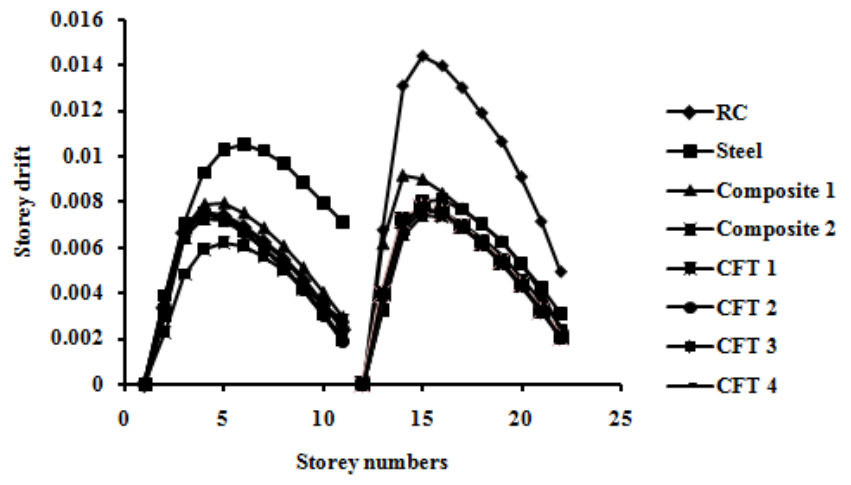

Figure 2: Story drift in $\mathrm{X}$-direction and $\mathrm{Y}$ direction

Story baseshear: As the base shear is the horizontal reaction to the lateral forces and horizontal forces results from the storey weight. From the figure3, it is observed that higher values were obtained in CFT1 model in the both the direction and the lowest values were in steel frame in $\mathrm{Y}$ direction. the base shear, that CFT 1 in $\mathrm{X}$ and $\mathrm{Y}$-direction has more base shear than RC, steel and other composite frames because CFT 1 has more weight than other frames. Steel frame has low base shear because of its low weight. Base shear value is increase in CFT frames.

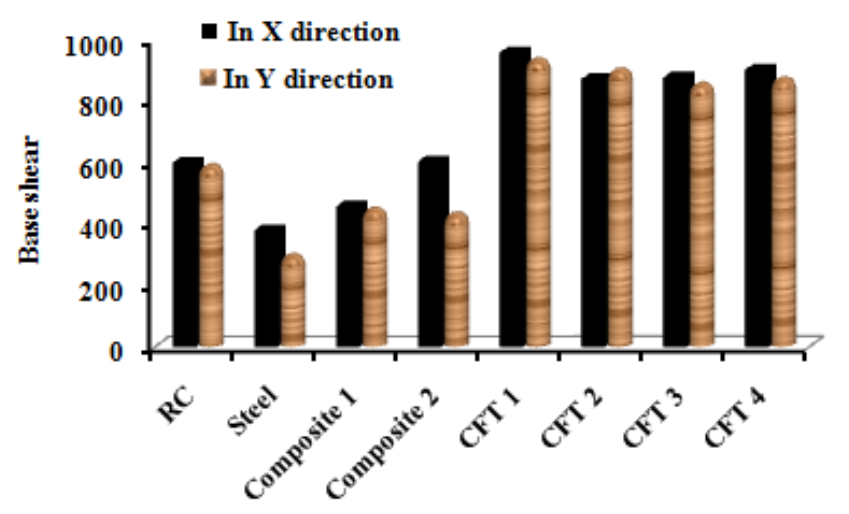

Types of model

Figure3.Story base shear in $\mathrm{X} \& \mathrm{Y}$-direction

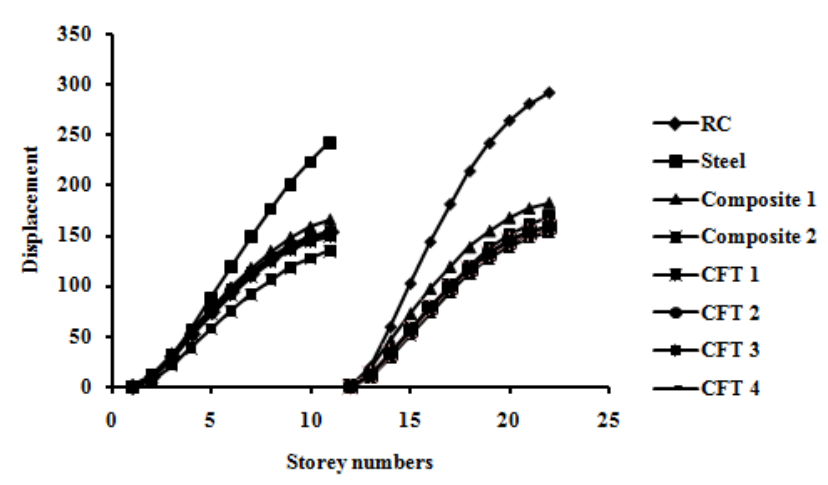

Figure 4.Story displacements in X-direction and Y direction

Storeydisplacement: The storey displacement verses storey numbers figure both in $\mathrm{X}$ and $\mathrm{Y}$ direction are shown in figure4.It is seen from the figure that steel frame model has more displacement in both direction. However composite 2 model has less displacement in $\mathrm{X}$ direction and CFT1 model has the less displacement in Y direction compared with other frame in this study. Further the displacement is increase with the increase in storey number of the frame and the maximum displacement at observed at $10^{\text {th }}$ story.

Axialforce .Axial force at top of building verses storey numbers of all the models is shown in the figure 5.It can be seen form figure 5 , that axial force is decrease with the increase in stories. CFT 1 model has maximum axial force at each story.. Steel frame has less axial force compare to other frames. Axial force in steel frame is decrease $31 \%$ than CFT 1 frame.

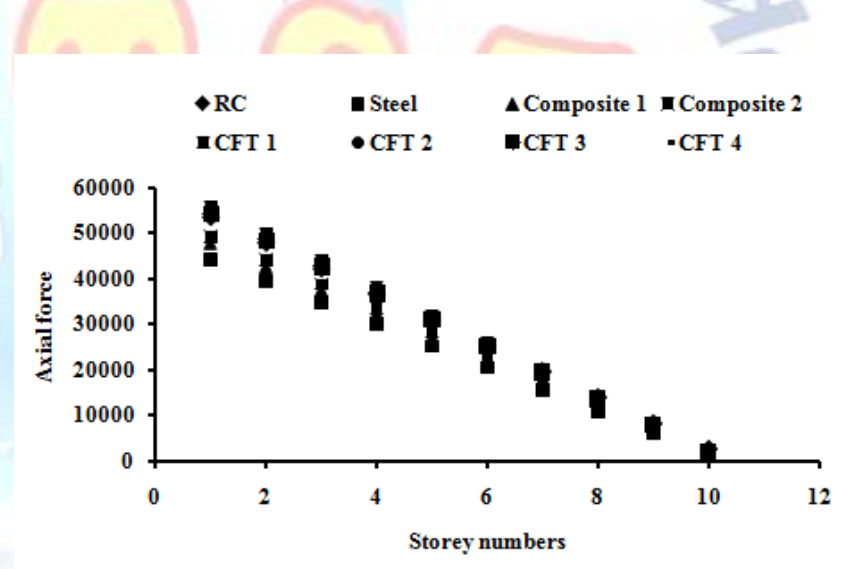

Figure 5. Axial forces at top verses stories

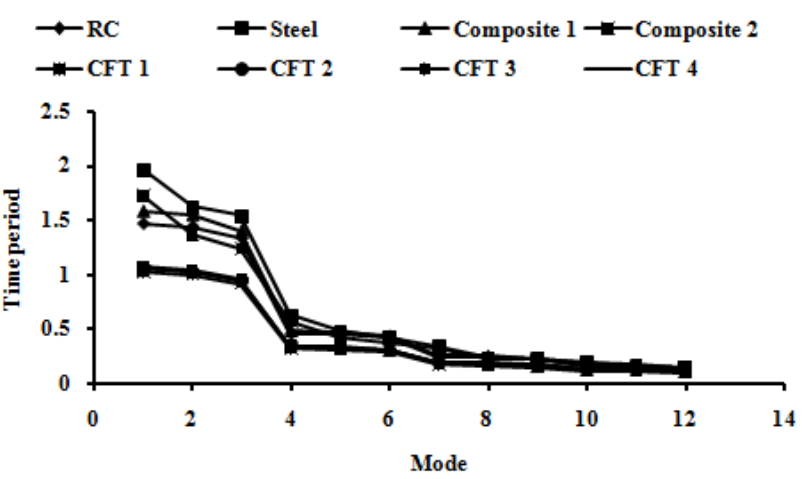

Figure 6. Time period at modes

Timeperiod: Time period verses modes for different cases are shown in figure 6.The time period is decreasing with the increase the mode in a similar fashion. The time period of the steel frame was 
observed much higher andCFT1 frame gets less time period. However the time period of CFT sections are less than the reinforced concrete frame structures.

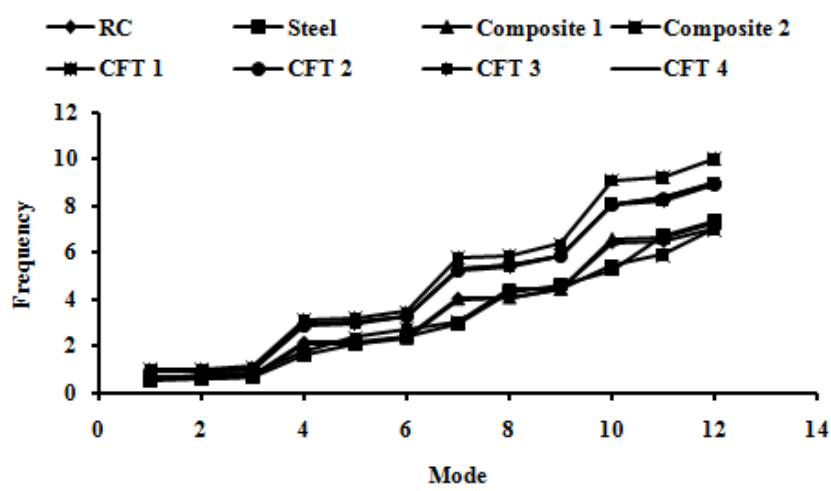

Figure 7.Frequency for different cases

Frequency: Observed frequency for different frames is shown in figure7. It is observed from the figure that CFT 1 model has more frequency as compare to other frames because CFT1 model has more stiffness than other frames further the composite 2 frames have less frequency as shown in graph.

Overturningmoment: Overturning moment for different frames both in $\mathrm{X}$ and $\mathrm{Y}$ direction are shown in figure8. It is observed that CFT 1 frame has maximum overturning moment in $\mathrm{X}$ - direction than other frame and composite 1 model has less overturning moment.

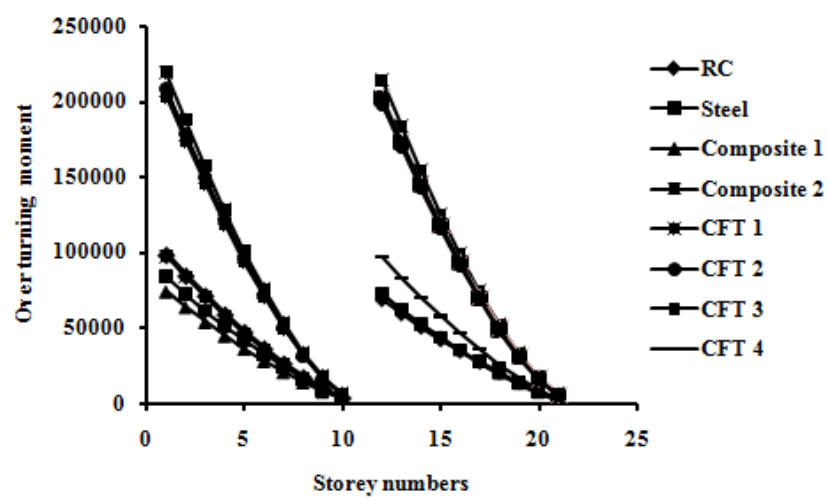

Figure 8. Overturning moment in $\mathrm{X}$ and $\mathrm{Y}$-direction for different cases

Storey shearforce: Storey shear force in both $\mathrm{X}$ and Y-direction for different frames are shown in figure9.It can be seen in the figure that storey shear force in X-direction decrease with the increase in the stories and CFT 1 model has more value as compare to other frames further the composite 1model has the lowest value of story shear force. However it is also seen that CFT frame model have more storey shear force than other steel, concrete and composite frames. The $10^{\text {th }}$ storey composite 1 model has lowest value than other frames in both $\mathrm{X}$ and $\mathrm{Y}$ direction.

Storystiffness: Story stiffness for different frames is shown in figure 10. It is observed that CFT 1 frame has more story stiffness in $\mathrm{X}$ and $\mathrm{Y}$ directions than other frames because CFT 1 has more weight as compare to other frames. At first and second story of composite 1 frame has low value of the story stiffness after second story steel frame has low stiffness.

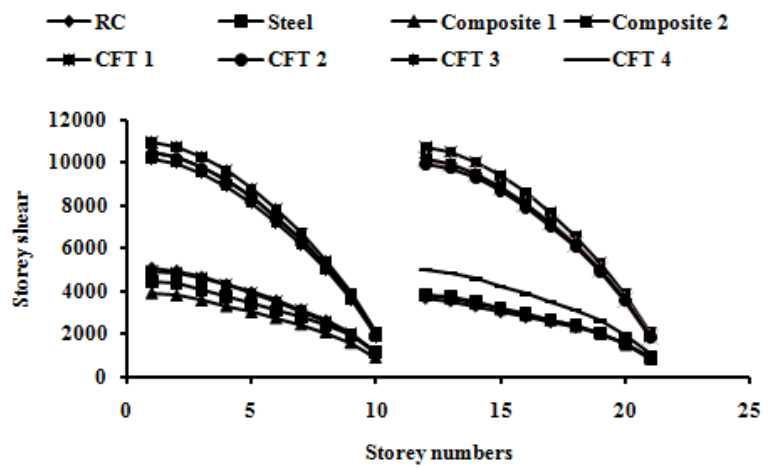

Figure 9.Story shear force $\mathrm{X}$ and $\mathrm{Y}$-direction for different frames

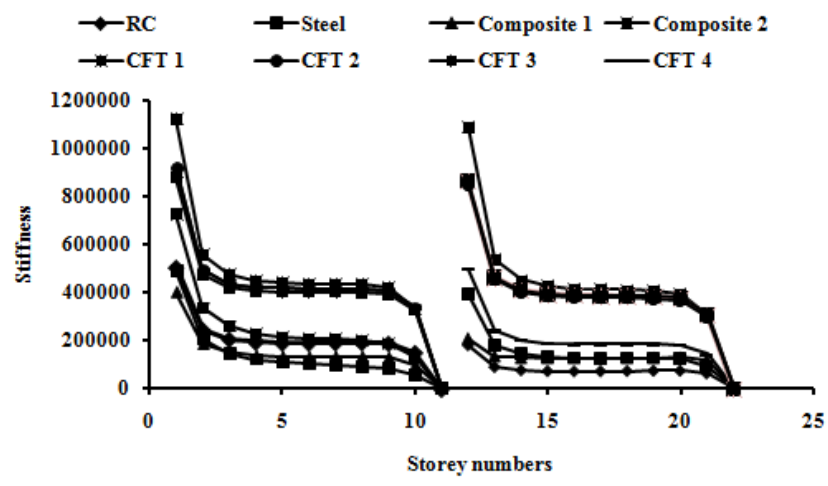

Figure 10.Story stiffness for different frames in $\mathrm{X}$ and direction

\section{CONCLUSION}

The main observations the analysis is summarized below. Comparing the analytical study of the entire eight models with reference to $\mathrm{RC}$ model it is observed that all the model behave identical for the parameters studies however the differences were pronounced in magnitude. Story drift in both $\mathrm{X}$ and Y-direction in steel frame model has more as compare the RC and other steel-concrete composite frames. The values of Base shear both in $\mathrm{X}$ and $\mathrm{Y}$ direction for composite model 1 and 2 has reduced by $\%$ and for steel model by \% compared to that of 
Reinforced concrete model, however the base shear for CFT1m CFT2,CFT3and CFT4 has increased to much compared to that of reinforced concrete model . Story displacement in $\mathrm{X} \& \mathrm{Y}$-direction in steel frames has maximum displacement as compare to other RC and steel-concrete composite frames because the steel frame has more ductile and have lowstiffness.Axial force in decrease as increases the stories and CFT 1 frame has maximum axial force up to $9^{\text {th }}$ stories and after that $\mathrm{RC}$ frame has more axial force than otherframes.Time period in steel frame has maximum because of it low stiffness value. CFT 1 frame has low time period because it has highstiffness.Frequency is inversely to the time period so CFT 1frame has high frequency than otherframes.Overturning moment in X-direction CFT 1 frame has maximum value and composite 1 frame has low value. In Y-direction CFT 1 has more value and steel frame has low value of overturning moment. All the CFT frames have maximum value of overturning moment than other steel -concrete compositeframes.All CFT frames have high value of story shear force and story shear force in $\mathrm{X} \&$ Y-direction CFT 1 frame has maximumvalue. Story stiffness in X \& Y-direction in CFT 1 has more as compare to other frames up to $9^{\text {th }}$ stories and after that CFT 2 has more value because of its more weight. In X-direction composite 1 frame has low value of story stiffness. The seismic behavior of CFT model gives the better performance compared to $\mathrm{RC}$, steel and other steel-concrete composite frames.

\section{REFERENCES}

[1] D. R. Panchal, P. M. Marathe, Comparative study of R.C.C, Steel and composite (G+30 Storey) building", Institute Of Technology, Nirma University, Ahmedabad- 382481, December, 2011, pp.08-10

[2] A. N. Shah, P. S. Pajgade, "Comparison of RCC and composite multi- storied buildings", International Journal of Engineering Research and Application (IJERA), ISSN: 2248-9622, Vol.3, Issue 2, March-April 2013,pp.534-539.

[3] S. A.Wagh, U.P Waghe, "Comparative study of RCC and steel concrete composite structure" International Journal of Engineering Research and Application (IJERA), ISSN: 2248-9622, Vol. 4, Issue 4 (Version 1), April 2014, pp.369-376

[4] Z. Mujawar, P.Sangave, " Comparative evaluation of reinforced concrete, steel and composite structure under the effect of static and dynamic loads". International Journal of Engineering Research and Applications (IJERA), ISSN: 2248-9622, Vol. 5, Issue 1( Part 5), January 2015,pp.41-44

[5] HajiraNausheen, Dr.H.Eramma .Comparison of Seismic Behavior of a Structure with Composite and Conventional Columns.International Research Journal of Engineering and Technology (IRJET) e-ISSN: 2395 -0056 Volume: 02 Issue: 08 | Nov-2015 PP 1556-1562

[6] N.V. Ganwani, S. S. JamkarComparative Study of RCC and Steel-Concrete Composite Building based on Seismic Analysis International Journal of Engineering Research \& Technology (IJERT) Volume 4, Issue 30. ISSN: 2278-0181 Published by, www.ijert.org IC-QUEST - 2016 Conference Proceedings ,Special Issue - 2016 PP 1-4

[7] A.S. Boke, k. R. Suryawanshi comparative study of r.c.c and steel-concrete composite $(\mathrm{G}+10)$ residential building. Journal of information, knowledge and research in Civil engineering Issn: $0975-6744 \mid$ Nov 16 to Oct 17 | volume 4, issue 2 pp 411-416

[8] P. S. Sanjay, S. R. Parekar ,Seismic Analysis of RCC, Steel and Steel Concrete Composite Frame International Journal for Research in Applied Science \& Engineering Technology (IJRASET) Volume 7 Issue VII, July 2019 pp 249-255

[9] T.G.N.C.Vamsi Krishna, S.V.Surendhar, M. S.R. Krishna.Comparison of Seismic Analysis of a Residential Composite and Rcc Structures International Journal of Innovative Technology and Exploring Engineering (IJITEE) ISSN: 2278-3075, Volume-8, Issue-6S3, April 2019pp 113-119

[10] M. AkifUddin, M. A. AzeemComparative Study on Seismic Behaviour ofcomposite and RCC plan Irregular StructuresInternational Journal of Engineering Research and Technology (IJERT) ISSN: 2278-0181 . Vol. 9 Issue 01, January-2020 pp162-168

[11] IS 456:2000, "Indian Standard code of practice for plain and reinforced concrete", Bureau of Indian Standards, New Delhi,India.

[12] IS 800:2007, "Indian Standard code of practice for general construction in steel" Bureau of Indian Standards, New Delhi,India.

[13] IS: 1893, Criteria for earthquake resistant design of structures general provisions for buildings, Part 1, Bureau of Indian Standards, New Delhi,2002.

[14] AISC 360-10, Specification of structural steel building, An American national Standard, American Institute of Steel Construction 